begin, and I have often been told that it does so early on the first Sunday of March, G.M.T.

What I said about the magpie beginning on the first Sunday (old style) was founded partly on report, but mainly on personal observation extending over some years at one breeding-place, where I have often seen them at work for the first time on this particular morning, and on one occasion in another locality on the same day.

This instinct is not confined to any particular tribe or order, but is common, I think, to all wild fowl, and the two instances given by Dr. Rae (vol. xxx. p. 7) of the regularity with which certain birds pass north to their breeding-grounds is precisely the point at issue, as I believe they begin work as soon as they arrive.

Scientific accuracy has not yet been directed to the subject, but there can be no doubt that from some cause, possibly a sharper and better defined division of summer and winter in former ages, all the feathered tribe have inherited an instinct in nest-building and in the time of their arrival at and departure from their breeding-grounds which guides them to a day in many cases without reference to the state of the weather.

WM. BROWN

I I2, West Regent Street, Glasgow, May 5

Watts's "Inorganic Chemistry"

THE review of my "Inorganic Chemistry" in NATURE of May I (p. 3) appears to have been written without much knowledge of the previous history of the work. The reviewer, indeed, writes as if he were criticising an entirely new book, whereas a glance at the preface might have shown him that the volume in question is the first part of the thirteenth edition of Fownes's well-known "Manual of Chemistry," the first edition of which was published in 1844

151, King Henry's Road, N.W.

\section{The Recent Earthquake}

I Notice that Mr. Topley, at the conclusion of his communication to you respecting the recent earthquake in Essex, remarks, "but at present we know of no observations in the central parts of Kent, Surrey, or Sussex." I wish therefore to mention, that although I did not myself notice anything in connection therewith, yet an invalid neighbour of mine, lying in bed, distinctly heard a rumbling noise about $9 \mathrm{~h} .20 \mathrm{~m}$. , and a moment afterwards perceived some pot plants in front of his window sway to and fro. This is the only incident with which I have been made acquainted.

The Observatory, Crowborough, Sussex, May 3

THE rise in the Essex waters detailed in my letter of last week still continues. Mr. Radforde Sharpe has kindly sent me the following additional heights that the water rises from Messrs. Courtauld and Co.'s well, at Bocking, Braintree, in inches above the surface of the ground:-

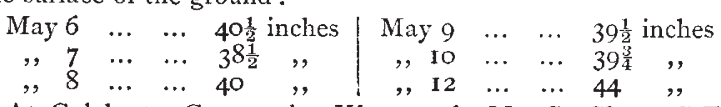

At Colchester Corporation Waterworks Mr. C. Clegg, C.E., reports the rise recorded is still maintained.

Museum, Jermyn Street, S. W.

\section{E. De Rance}

W. H. FRANCE.-Any good entomological text-book will give you the information you ask for.

\section{NOTES ON EARTHWORMS}

FVER since our great naturalist called attention to the common earthworm, we watch them with entirely different eyes as they creep timidly out on to the lawn or hurry across the gravel walk; as they collect the dead leaves or bits of string and cloth we may have dropped the evening before, or heap up their household refuse outside the entrance to their home.

He long ago pointed out its importance as a geological agent. The surface of the ground would be very different were it not that the earthworm is for ever at work bringing in the decaying vegetation and converting it into mould.
And, more than this, the superficial deposits are often modified to a considerable depth by the earthworms, which, carrying the earth moutbful by mouthful, and the gravel stone by stone, invert the order of stratification.

But we must not push this explanation of the origin of the universal surface mould too far. I received one caution from Darwin himself, many years ago when I was talking to him about the manner in which the chalk with which the land was dressed in Kent worked down. He told me to be careful to bear in mind the action of the great Kentish plough as it year by year turned swathe after swathe down the slopes. The result of this plough-down is clearly aistinguishable from wormmould. In his work on earthworms also he refers to another mould-forming agent of more universal operation and hardly less important cumulative effect. My attention was first directed to it by a lecture I heard delivered by Stoppani in Milan many years ago, in which he was explaining the action of the wind in modifying the surface of the earth, and especially in carrying dust, organic and inorganic. Richthofen and Drew have thus explained the origin of the loam that covers half Asia; and $\mathrm{Mr}$. Clement Reid has recently extended the same kind of observation to Great Britain (Geol. Mag., April i 384). Without this addition we can hardly explain how earth. worms could find the material for the manufacture of the mould which often fills the interstices of the ruins of a buried city.

We find, commonly, isolated tumps of moss-covered soil, and every gradation from that up to the large patches of mould which hang like little gardens on each sheltered ledge, where the greater part of the material must evidently have been carried from elsewhere and not have been brought up from below ; where it is obvious, from the character of the rocks, that the principal part of the mould cannot have been derived so much from them as from the wind-carried fragments of organic and inorganic material and the decomposition of the vegetation that soon began to grow upon it.

But we find also that the earthworms soon appear in such places, and set to work to mix up and modify all this various stuff that has by various agencies been brought together.

As squirrels, burying acorns and nuts in the autumn, have planted many an oak forest and hazel grove, so it is probable that the earthworms plant many of the ash and sycamore trees that we see perched in out-of-the-way corners, where it is difficult to explain how the blown seed can have got covered by mould enough to allow it to germinate. If an overhanging tree drops the seed, or the wind carries it anywhere near the worm's feedingground, it is dragged in and planted in leaf mould, and kept moist till spring time. At this time of the year we see clusters of sycamore seedlings growing up together out of the little worm-hills into which they had been dragged heavy end first.

It is therefore interesting to inquire into the various reasons that should make earthworms travel and occupy new ground. Round the margin of an overcrowded colony we should expect them to spread. They cannot live under water, so they have to move away before a flood. It has been stated that "they may live when completely submerged in water for nearly four months" (Romanes reviewing Darwin, NATURE, vol. xxiv. p. 553). But they nere killed off by a flood of a couple of days' duration in the Backs of the Colleges at Cambridge in August 1879. Some of them seem to have got on to the paths, which are raised above the surrounding meadows, and there died. Where the greatest number were found dead the ground had been submerged for a longer time. The following carefully recorded observations by the Rev. Henry Russell, of St. John's College, are worth noting :-..

"On Sunday, August 3, 1879, our paddock (the inclosed space in which the men play at lawn tennis, in front of the 